\title{
Truce agreed in chip war
}

Washington

JuST minutes before midnight on 30 July, Japanese and US negotiators reached a comprehensive agreement on trade in semiconductors. Under the terms of the five-year agreement, the Japanese government will both help US semiconductor companies to increase their share of the Japanese market and stop Japanese companies from "dumping" chips on international markets. The US industry is well pleased with the agreement. But the industry knows that a key question remains; can it be enforced?

Reaching an agreement before midnight on 30 July was crucial. That was the statutory deadline for a Departme',t of Commerce decision to impose permanent dumping duties on erasable programmable read-only memory chips (EPROMs). The Commerce Department had already made a preliminary judgement that Japanese manufacturers were dumping EPROMs - selling them at less than fair value considering their production costs - and chip importers have been posting bonds against possible imposition of duties. Under the agreement, both the dumping case against EPROMs, and a similar case against 256 kilobyte dynamic random access memory chips (256K DRAMS) with an 1 August deadline. will be suspended. In exchange, the Japanese government agrees to ensure its manufacturers sell products only at "fair market value". Also suspended is an unfair trading case being pursued by the office of the US Trade Representative, which could have resulted in sanctions against Japan.

To increase the US share of the Japanese semiconductor market, Japan will establish an organization to assist foreign manufacturers' sales efforts, and will also promote long-term relationships between US manufacturers and Japanese semiconductor users. While there is no specific target, the US market share in Japan is expected to increase to 20 per cent by the end of the five-year agreement. US sales at present account for $8-10$ per cent of the Japanese market.

Another key element of the agreement, according to George Scalise of the Semiconductor Industry Association (SIA), is that US companies manufacturing in Japan will be given the same rights and privileges as Japanese companies, which is likely to increase the market share for the US industry.

In the week just before the signing of the agreement, Japanese manufacturers made a large number of sales to US customers. While the agreement on EPROM dumping became effective on 31 July, 256K DRAMS can be shipped to cus- tomers at any price agreed before 1 August until 15 September. After that, fair market pricing will prevail. But US industry spokesmen concede that a large number of chips can be delivered to US customers during that time. Sales of $256 \mathrm{~K}$ DRAMs now account for 17 per cent of the total US semiconductor market.

To prevent future dumping, Japanese companies will provide data on pricing of EPROMs and 256K DRAMS to the Department of Commerce on a regular basis. The Japanese Ministry of International Trade and Industry will keep track of pricing data on other semiconductors, as well as products to be shipped to markets other than the United States. The United States

\section{Technology journals}

\section{Time to learn Japanese}

\section{Washington}

FEARFul that US industry is not doing enough by itself to tap the voluminous output of Japanese scientific and technical literature, the US Senate is expected this week to agree to set aside $\$ 1$ million per year for efforts to make access easier. How the money will be spent has not yet been decided. but a possibility is that special representatives in Tokyo of the US Commerce Department will seek out the best from the Japanese literature and ensure that it is available in translation to US researchers.

Even supporters of the measure acknowledge, however, that the amount specified will do little to right the huge imbalance in the flow of technical information. The total number of US translators capable of handling difficult technical material in Japanese is small, perhaps only 200 , with most of them working for one company. Japanese efforts to translate Western literature into Japanese, by contrast, are impressive: over 5,000 scientists and engineers are said to abstract routinely some 10,000 foreign and domestic journals, as well as other sources.

The Japanese Technical Literature Act directs the US Secretary of Commerce to redirect $\$ 1$ million from other Commerce Department activities to the monitoring and dissemination of Japanese technical developments. So far, the department has agreed to find only $\$ 250,000$. The act requires the department to consult businesses. professional societies and libraries in order to find out what is in most demand; it must, however, avoid offering material already sold by commercial companies.

A probable formula is that the Commerce Department's International Trade Administration will represent the Nation- can request immediate 14-day consultations to resolve dumping questions and retains the right to initiate its own antidumping investigations that could result in the imposition of dumping duties. The issue of third-market sales, and the possibility that chips would be dumped in small countries for trans-shipment to major customers at cut-rate prices. proved especially divisive in the negotiations. Although Japanese companies never admitted to dumping during the negotiations, Michael Gadbaw of SIA says they nevertheless "promised never to do it again".

What gives US negotiators confidence that Japan will adhere to the terms of the agreement is the threat that the suspended dumping and unfair trade cases can be reinstituted. But many believe that it will take a lot of work to turn these commitments into reality.

Joseph Palca al Technical Information Service (NTIS. also part of Commerce) in Tokyo, and will then offer the information culled to US industry and academic institutions for a nominal fee. NTIS already monitors some Japanese government publications, but spent only $\$ 18,000$ last year on translation. The future of NTIS is, however, uncertain; the federal government has proposed turning over the agency in whole or in part to the private sector, and NTIS staff fear they may never see the money. The International Trade Administration. in contrast, already has ideas about what it would do with the promised $\$ 250,000$ : produce another two of its in-depth reports on Japanese technology, four of which were produced recently for $\$ 500,000$ and were sell-outs.

By far the largest Japanese translating operation in the United States is the private-sector Japanese Technical Information Service (JTIS) of Media, Pennsylvania, a subsidiary of University Microfilms. JTIS (which claims to employ most of the qualified Japanese translators in the United States) abstracts some 600 Japanese journals for its industry clients and offers full translations as requested. But at $\$ 5,500$ per year for a subscription to its abstract journal. sales have been restricted to major companies, with only 150 or so paid-up subscribers.

Justin Bloom, a former science adviser at the US Embassy in Tokyo, says that if JTIS's service fails to prosper it will show there is "no demonstrable US interest" in access to Japanese literature. But he is sceptical about the new act. describing it as "laudable in principle but meaning little in practice". Bloom says that in Tokyo, even with a staff of 22 , he was hardly able to make an impact in monitoring Japanese technical literature.
Tim Beardsley 